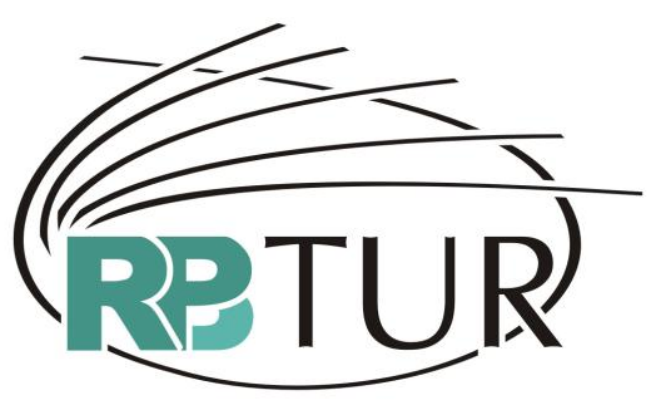

REVISTA BRASILEIRA DE PESQUISA EM TURISMO

\title{
PELAS FRONTEIRAS DO MEDO: RESISTÊNCIA AO PROCESSO DE IMPLANTAÇÃO DO TURISMO NA ILHA DO MEDO - MARANHÃO, BRASIL
}

\author{
FEAR BOUDARIES: RESISTENCE TO TOURISM PROJECTS AT \\ ILHA DO MEDO (ISLE OF FEAR) - MARANHÃO STATE, BRAZIL
}

\section{EN LAS FRONTERAS DEL MIEDO: RESISTENCIA AL PROCESO DE IMPLANTACIÓN DEL TURISMO EN ILHA DO MEDO (ISLA DEL MIEDO) - ESTADO DE MARANHÃO, BRASIL}

\begin{abstract}
Resumo: Este artigo visa analisar o processo de implantação do turismo comunitário na Ilha do Medo, no Maranhão, e a reação dos autóctones frente à chegada dos turistas. Trata também do diálogo que se estabelece entre os nativos e os planejadores de turismo na Ilha do Medo. A reação dos autóctones à tentativa de transformação da Ilha em um novo atrativo turístico em São Luís demonstra a preocupação constante dos ilhéus em manter o modus vivendi local. Para isso, os autóctones utilizam o medo como estratégia para manter os "invasores" distantes. Além de possibilitar uma reflexão sobre as relações que se estabelecem entre nativos e turistas, a análise do processo de implantação do turismo nos permite compreender as redes de relações sociais tecidas entre os planejadores de turismo, os nativos e o etnógrafo em campo, além de apreender os fluxos que se estabelecem pelas fronteiras do medo.
\end{abstract}

Palavras chave: Turismo. Turistas e autóctones. Resistência. Medo. Ilha do Medo (Maranhão, Brasil).

Abstract: The article analyses a project for communitarian tourism at Ilha do Medo, Maranhão State and the local's reaction to tourists. It also analyses dialogues between natives people and tourism planners in the place. Local's reaction to the attempt of turning the island into a new attraction at San Luis indicates their concern in preserving their way of life. To do so they use fear as a strategy to keep "invaders" at a distance. The analysis made possible to reflect on relationships between tourists and

\footnotetext{
${ }^{1}$ Professora da Universidade Federal do Maranhão (UFMA) Programa de Pós-Graduação em Antropologia Social da Universidade Federal de Santa Catarina (PPGAS/UFSC). Email: emilenesousa@yahoo.com.br
} 
native people, understand the social network woven among tourism planners, natives and ethnographers in the field, as well as learning the flux at the boundaries of fear.

Keywords: Tourism. Tourists and locals. Resistance. Fear. Ilha do Medo (Maranhão, Brazil).

Resumen: El artículo analiza el intento de implantación del turismo comunitario en la Isla del Miedo, en el estado de Maranhão y la reacción de los habitantes locales al turismo. Analiza también el diálogo entre la población local y los planificadores de turismo en el lugar. La reacción de los nativos al intento de transformar la isla en un nuevo atractivo turístico para la ciudad de San Luis muestra su preocupación en mantener su estilo de vida. Para ello utilizan el miedo como estrategia para mantener los "invasores" a distancia. El análisis permitió reflexionar sobre las relaciones entre nativos y turistas, entender la red social tejida entre planificadores de turismo, nativos y etnógrafos en campo así como entender los flujos en las fronteras del miedo.

Palabras clave: Turismo. Turistas y población local. Resistencia. Miedo. Isla del Miedo (Maranhão, Brasil).

\section{Sobre a Ilha do Medo}

A Ilha do Medo está localizada a noroeste da ilha de São Luís, distando $6.380 \mathrm{~m}$ da Praia Grande, em linha reta. Esta é mais uma das várias ilhas que compõem o arquipélago do Golfão Maranhense. O acesso à ilha se dá por via marítima, através de embarcações rústicas como jangadas, canoas, igarités e catamarãs. O tempo de travessia de São Luís a Ilha do Medo é de 10 a 30 minutos.

A população da Ilha consiste de uma comunidade pesqueira. As principais atividades desenvolvidas pela comunidade, além da pesca, são a agricultura de subsistência e a extração de babaçu.

No local não existe infra-estrutura como água encanada, rede de esgoto e energia elétrica. A inexistência de água encanada é substituída pelo abastecimento de poços e pequenas fontes de água originadas das formações rochosas existentes no lugar.

De acordo com os relatos de alguns dos 36 moradores da Ilha do Medo, o local começou a ser habitado pela família de um senhor de 56 anos que já habita a ilha há mais de 40 anos. Sua chegada a Ilha foi seguida a de outra família advinda do município de São João Batista, interior do Maranhão, e estas duas tornaram-se as famílias nucleares do local. 
A propriedade da Ilha do Medo está localizada no município de São Luís, mas pertence à União sendo monitorada pela Marinha do Brasil. Por essa razão todas as ocorrências extraordinárias são comunicadas a Marinha e, quando necessário, transformadas em boletins de ocorrência.

Sobre o nome da ilha, na minha "exploração" paralela ao da equipe de planejadores de turismo ouvi narrativas sobre os mais estranhos mausassombros, ocorrências sobrenaturais e divinas que fizeram da Ilha um lugar de histórias sinistras e sem explicações, de mistério e perigo: a Ilha do Medo (SOUSA, 2007).

\section{De invasores a visitantes}

No início de 2006 recebi da Secretaria Municipal de Turismo/SETUR ${ }^{2}$ de São Luís um convite para acompanhar uma equipe de profissionais das mais diversas áreas de conhecimento à Ilha do Medo, cuja realidade era desconhecida pela maioria dos moradores de São Luís e redondezas.

O objetivo da "exploração", como era chamada a nossa incursão à Ilha do Medo pelos turismólogos ${ }^{3}$, pedagogos, assistentes sociais, geógrafos, topógrafos, arquitetos e biólogos que compunham a equipe, além de mim, era planejar o turismo com bases comunitárias ${ }^{4}$ na Ilha.

Como antropóloga, minha tarefa não era mais do que promover e mediar o diálogo entre os nativos e a equipe, na tradução de idiomas culturais que faz do antropólogo, aos olhos dos hermeneutas, um intérprete. Neste sentido, deveria explicar aos nativos a razão da presença da SETUR na Ilha, buscando termos menos técnicos, mais informais para que a importância do turismo para

\footnotetext{
${ }^{2}$ A Secretaria de Turismo de São Luís/SETUR foi criada em dezembro de 2003 e, segundo seu estatuto, "tem como função promover o desenvolvimento do turismo sustentável no município de São Luís, favorecendo a valorização do patrimônio cultural e natural; a geração de trabalho e renda; e o fortalecimento da identidade e dos valores locais".

${ }^{3}$ Diferencio no texto o turismólogo - estudioso de turismo - dos planejadores de turismo.

4 De acordo com o projeto, o turismo com bases comunitárias consiste em um turismo planejado para que os nativos sejam os responsáveis diretos pelo entretenimento dos turistas no local, devendo, portanto, o projeto respeitar as regras locais, o modo de vida, a organização social do povo além de utilizar os próprios nativos como fornecedores dos mais diversos serviços como os de transporte, deslocamento, guia de turismo etc..
} 
a região fosse entendida, bem como para vida deles mesmos e o "respeito" da SETUR pelos habitantes e seu modo de vida, razão da proposta de implantação do turismo com bases comunitárias.

Por esse motivo, durante a viagem, os turismólogos da equipe explicavam-me como o crescente fluxo de turistas na Ilha tinha chamado a atenção dos moradores, que procuraram a SETUR manifestando o desconforto e a insatisfação dos habitantes em relação à nova situação.

A SETUR, ao receber o morador que lá estivera reclamando dos "invasores" na Ilha, propôs uma visita ao local e explicou que seria possível um turismo planejado, que não ofereceria riscos ao modo de vida dos habitantes e que seria supervisionado diretamente pela prefeitura e sua Secretaria de Turismo. Então, passou a planejar a implantação do turismo com bases comunitárias e me convidou para mediar esse primeiro encontro com os nativos. Assim, parti em busca do desconhecido.

Quando atracamos na Ilha do Medo, tendo que caminhar em meio à água e lamaçal até a praia, ficou à vista a falta de estrutura local de que se ressentiria a SETUR para transformar a Ilha em atrativo turístico. A esta altura, eu estava curiosa em conhecer a Ilha, cuja história se mantinha como mistério e cuja distância cronometrada em trinta minutos de viagem de catamarã parecia um abismo entre suas praias lindas e o litoral ludovicense.

$E$, naquele momento, com os pés na água, além de deslumbrada com a beleza do lugar que os meus olhos descobriam e que muitos caracterizariam sob "o mito da natureza intocada" (DIEGUES, 1996), eu estava atenta aos olhares dos moradores que de longe acompanhavam a nossa chegada.

No restante da manhã ensolarada, que rapidamente ficou nebulosa, passamos de casa em casa, apresentando-nos aos residentes e falando sobre o objetivo da "exploração", que era estudar o local e programar as construções e investimentos a serem feitos pela prefeitura para tornar a Ilha do Medo em 
mais um dos atrativos do chamado turismo náutico ${ }^{5}$ que está despontando em São Luís.

Mas esta tarefa exigia dos profissionais ali reunidos um esforço contínuo em explicar e justificar a importância de que o turismo na Ilha fosse planejado. Os principais argumentos utilizados eram de que o turismo era inevitável, como a chegada dos primeiros "visitantes" já havia demonstrado, e que, diante disso, os habitantes do local deveriam buscar formas de lucrar com o turismo, e a prefeitura de São Luís estava disposta a ajudá-los, programando o turismo para que não houvesse danos aos ilhéus.

A partir daí, teve início uma polêmica discussão. Os habitantes da Ilha do Medo passaram a narrar a chegada dos "invasores", categoria utilizada por eles cada vez que se referiam aos turistas que apareciam esporadicamente ao local e, com o passar do tempo, com maior freqüência. A narrativa era marcada pela estranheza de ver o lugar onde os habitantes eram todos conhecidos e parentes - cuja melhor definição era "nossa casa", como se referiam à Ilha - parecer aberto a pessoas estranhas, que passaram a freqüentá-lo sem serem apresentados aos moradores, sem cumprimentá-los, invadindo o seu cotidiano, instalando-se lá por dias, causando barulho, transtorno e deixando lixo por toda parte, até o momento em que partiam sem se despedir.

Essas visitas, que eram esporádicas, tornaram-se, segundo os próprios moradores, cada vez mais sistemáticas, e em grupos cada vez maiores de "invasores". Sempre que se referiam aos turistas, eles utilizavam o termo

5 O turismo náutico caracteriza-se pela utilização de embarcações náuticas na atividade turística. Ele pode ser fluvial, lacustre, marítimo ou de represas. Pode ainda ser de dois tipos: o que faz uso de embarcações náuticas com finalidade de movimentação turística, quando a motivação do turista e a finalidade do deslocamento é a embarcação em si; e o que faz uso de embarcações náuticas como meio de movimentação turística, em que o transporte náutico é utilizado especialmente para fins de deslocamento, para o consumo de outros produtos ou segmentos turísticos, sendo este último o turismo náutico a ser desenvolvido na Ilha do Medo. 
ISSN: $1982-6125$

"invasores", e a atividade turística era denominada "invasão", em frases como: "quando a invasão começou...". 6

Enquanto os turismólogos tentavam convencê-los de que poderiam estabelecer uma parceria com a SETUR, obter lucros e melhorar a qualidade de vida no local com bons empreendimentos turísticos e ganhando uma infraestrutura oferecida pela prefeitura, os autóctones preocupavam-se com sua tranqüilidade, seu modo de vida e tradição. O medo presente no discurso deles era o medo da mudança repentina de um modus vivendi experienciado há quarenta anos por gerações.

Agindo como "colonizadora", a equipe7 demonstrava total insensibilidade em relação aos moradores e aquilo que eles defendiam: seus valores, sua tradição, seu modo de vida. Prova disso é que, na medida em que falavam com os moradores em casa, como se esperassem deles algum tipo de apoio ou mesmo uma autorização, eu observava pelas janelas, de longe, topógrafos, biólogos, arquitetos e geógrafos atuarem lá fora, entre a flora e a fauna, rabiscando em pranchetas, apontando para os montes, medindo terrenos, procurando os pontos estratégicos para a construção de poços, trapiches, mirantes, restaurantes, pracinhas, pontos de descanso, sinalização de trilhas ecológicas e daí por diante.

Distraída e incomodada com o que observava lá fora, pela moldura da janela, fui discretamente abordada com um toque por uma das turismólogas

\footnotetext{
${ }^{6}$ Lembramos que o turismo é definido como "um tipo específico de deslocamento praticado por um tipo específico de viajante que é o turista, diferenciado de outros tipos de viajantes por características como o objetivo da viagem, o tempo de permanência fora de casa e o estado de espírito" (Banducci Jr.; Barreto, 2001), o que torna indiferente o planejamento turístico do local visitado ou não. Ou seja, o turismo parece definido pela ação do turista e não como uma rede de relações sociais culturalmente definidas. Comumente não se tem pensado o turismo pelo conjunto do sujeito que se desloca, a sociedade receptora, as relações que se estabelecem com os nativos, elementos que constituiriam os chamados "encontros turísticos". 7 Vale ressaltar que a equipe de profissionais que participa das "explorações" da SETUR não é formada pelo quadro permanente da própria Secretaria de Turismo, mas é constituída de convites a profissionais a cada vez que surge uma demanda a ser atendida. Como afirma Banducci Jr.: "os planejadores de turismo, ou seja, aqueles 'arquitetos' que constroem a oferta turística (em empresas privadas ou públicas) - o chamado 'produto turístico' para ser usufruído pelos turistas -, nutrem-se de vários ramos do conhecimento" (Banducci Jr., 2001, p.9).
} 
sentada ao meu lado que, cansada de contra-argumentar com os moradores me indagou baixinho: "você não vai falar nada?", ao que eu respondi desconsertada: "estou achando o diálogo um pouco complicado", o que ela prontamente inferiu: "então! E não é por isso que você está aqui?".

Naquele momento entendi a delicadeza do trabalho do antropólogo a que se referia DaMatta no seu "O ofício do etnólogo: ou como ter um anthropological blues" (DAMATTA, 1978). O antropólogo é realmente convidado, não raras vezes - e nem sempre pelos nativos, acrescento - a exercer o papel de mediador em debates que não o agradam nem ética nem politicamente.

Mas esse não era o único problema, pois, se no fazer antropológico a relação etnógrafo/nativo já nos parece tensa, o que dizer quando esta relação bipolar se transforma num triângulo que passa a envolver etnógrafo, turismólogos e nativos? Aliás, "a etnografia está relacionada à experiência das relações de poder entre nativos e etnógrafos" (GONÇALVES, 2002).

Neste caso, as relações de poder se estendiam para além dos nativos e do etnógrafo aos planejadores do turismo. Diante disso, o exercício etnográfico a ser realizado por mim exigia a transformação constante dos profissionais do turismo, além dos nativos, em meu objeto de estudo. Esta experiência se torna ainda mais densa na medida em que eu ocupo um espaço na dialética dos olhares: dos turismólogos e dos nativos sobre os turistas; dos turismólogos sobre os nativos; e dos nativos sobre os turismólogos. Assim, construiu-se uma rede de relações tensas e contraditórias, cujo emaranhado aprisionou a mim mesma. Minha principal tarefa seria então desvendá-la.

Através do olhar dos turismólogos, eu buscava enxergar os turistas sob outros aspectos e não apenas como intrusos, como comumente se faz na antropologia do turismo (ARAúJO, 2005). E esse olhar conflitava com o olhar dos nativos, que viam nos turistas o desejo de invadir e destruir aquilo que eles tanto protegiam: seu cotidiano.

Devo ressaltar que a minha experiência na Ilha do Medo foi marcada pela tentativa de implantação do turismo, que até agora não se efetivara. Diante 
ISSN: $1982-6125$

disso, os aspectos expostos neste trabalho resultam muito mais da análise das relações entre a equipe planejadora de turismo da SETUR de São Luís e os nativos da Ilha do que da relação estabelecida entre os nativos e os turistas, uma vez que a presença dos turistas na Ilha se dava esporadicamente, numa espécie de turismo avulso ou não planejado. Deste modo, as informações contidas neste artigo sobre a relação entre nativos e turistas se fundamentam na análise do discurso dos nativos, consolidando-se numa espécie de estudo das representações dos turistas pelos nativos da Ilha do Medo.

Cabe salientar que as representações de um determinado grupo jamais se expressam como um conjunto harmonioso ou coeso, apresentando sempre alterações a depender de quem fala e de onde está falando. Se, em se tratando de uma mesma categoria analítica, estas variações nas representações sobre um mesmo tema são evidentes, o que dizer da complexidade de relações que envolvem os discursos diferenciados de homens, mulheres, jovens, adultos, idosos e crianças? As contradições internas de um grupo são inúmeras e devem ser consideradas em sua complexidade.

Por essa razão, não concebo as representações dos nativos ouvidos como predominantes ou hegemônicas no que se refere às impressões dos nativos da Ilha do Medo sobre o turismo e os turistas. Entretanto, acredito que estas representações são significativas para uma análise da reação destes nativos frente ao processo de implantação do turismo comunitário no local.

\section{O medo como estratégia e o paradoxo do turismo}

Após o apelo da turismóloga para que eu tomasse partido na discussão optei, então, por deixar a casa e buscar lá fora outros objetos e pessoas com quem pudesse interagir sem o peso da "colonização". Iniciei conversas paralelas em outros ambientes, menos formais como a cozinha, a calçada, uma varanda, ou a própria praia e busquei informações distintas daquelas que "meus pares" pleiteavam. 
Originei diálogos perguntando sobre famílias, parentesco e crianças. Animais e plantações. E até mesmo a origem do nome dado a Ilha. E eis que quando menos esperamos os dados aparecem construindo um objeto que para mim veio praticamente ao meu encontro. O meu interesse longe de ser a implantação do turismo com bases comunitárias ou a Ilha do Medo como um novo destino turístico, passou a ser as relações que se estabeleciam entre os planejadores do turismo, nativos e turistas, sem deixar de fora aquela que se estabelecia comigo mesma.

A minha saída do círculo de profissionais naquele instante, e mesmo a distância espacial que se colocava entre mim e eles, foi-me favorável. Um favorecimento que se veio somar ao meu silêncio ao longo de toda a discussão, quando eu parecia ser a única que apesar de estar ali junto aos "colonizadores" - que como os portugueses no Brasil cruzaram os mares e chegaram em suas naus oferecendo melhores condições de vida a todos - não argumentava em favor do turismo como necessário, o inevitável ou conseqüência da inexorável lei do progresso.

Se por um lado, como pesquisadora e "de fora", eu parecia igual àqueles que insistiam em convencê-los sobre aquilo que os ilhéus menos desejavam, por outro lado, o meu silêncio e o meu interesse por assuntos diversos daqueles aproximou-me dos moradores e me pôs em contato direto com as histórias do local.

Descobri então, em meio às narrativas de mal assombro uma tentativa de assustar as pessoas que pensassem em se aproximar do local, mantendo aqueles que não pertenciam à comunidade, distantes. Essas narrativas com várias versões sobre o mesmo tema (o medo) iam desde o perigo do acesso ao local - caracterizado por um trecho denominado Boqueirão de extrema profundidade situado exatamente na circunferência em que estava a Ilha - até corpos de pessoas estranhas que aparecem em poços, pessoas que desaparecem da Ilha e gritos desesperados ouvidos pelas matas nas madrugadas. Todos esses acontecimentos tinham como vítimas, estranhos e/ou forasteiros que apareciam pelo local e nunca, alguém da comunidade. 
O medo emergia então como um dispositivo através do qual os moradores tentavam manter os citadinos distantes, acreditando reduzir 0 número dos que se arriscavam a transpor o trecho que circundava a Ilha, chamado Boqueirão, descrito como extremamente profundo e perigoso, devendo ser ultrapassado somente por aqueles que conheciam bem o local, no caso, somente os moradores da Ilha ${ }^{8}$.

Os nativos demonstravam muita satisfação e interesse em falar para mim sobre as condições de vida no local, de como a Prefeitura nunca se preocupara com eles; de como a Marinha era responsável pelo território, mas não os ajudava; de como os habitantes compunham uma grande família, todos parentes, conhecidos, amigos; da vida tranqüila, a mesma tranqüilidade que trouxera à Ilha os primeiros habitantes do local e agora parecia ameaçada pelos "invasores", os intrusos.

Num desses depoimentos uma senhora contou que seu marido, indo pescar pelas redondezas: "na hora que foi jogar a rede, quando deu fé, subiu um canudinho da água, quando ele pensa que não: um homem!". Segundo o seu depoimento e a descrição que fez do sujeito que emergiu da água, percebi que se tratava de um mergulhador, embora as águas turvas do litoral ludovicense não sejam uma atração à prática do mergulho. Esta situação fora esclarecida na busca de dados históricos sobre o local quando eu soube das naus que naufragaram no Boqueirão de fronte a Ilha, que passou a constituirse num dos trajetos dos caçadores de tesouros submersos no Brasil.

O mais interessante se deu quando, ao indagar sobre a história do local, uma das primeiras moradoras de lá me falou que já haviam escrito sobre a

8 Em outubro de 1535 partiu de Portugal uma esquadra, comandada por Aires da Cunha, composta por dez embarcações, com uma tripulação total de novecentos homens, fortemente armada e com cento e treze cavalos a bordo. Tinha a missão oficial de tomar posse da capitania Maranhão em nome de seu donatário, João de Barros. Em março de 1536, quando a esquadra chegava às costas do Maranhão, fortes chuvas e ventos assolavam a região e, provavelmente devido a estas condições climáticas adversas, a nau capitânia desapareceu nos baixios do Boqueirão defronte a Ilha do Medo. Além desta, outras embarcações da esquadra naufragaram próximas à Ilha do Medo.

Já em 1864, gravemente enfermo, o poeta maranhense Gonçalves Dias é aconselhado em Paris a voltar ao Brasil, quando o seu navio, o Ville de Boulogne naufraga nas cotas do Maranhão, nas proximidades da Ilha do Medo, e todos se salvam, exceto Gonçalves Dias. 
ISSN: $1982-6125$

Ilha e a história havia se transformado em livro. Curiosa, pedi que me deixasse ver a obra e indaguei sobre quem era seu autor, ela afirmou ser alguém que eles não conheciam e que o livro tinha sido encontrado na cidade de São Luís por um dos moradores que o comprara e trouxera. Insisti para que me mostrasse e demonstrando zelo, ela me disse que só ela guardava a obra. Como um documento sagrado, foi buscá-lo dentro de seu guarda-roupa, envolto de um plástico que deveria conservá-lo.

Estendeu para mim então, uma obra em ótimo estado editada por uma série denominada Coleção Aventuras de obras fictícias, cujo teor é aventura pensado para um público adolescente, de autoria de um professor aposentado da Universidade, cujo título em letras grandes na capa era A Ilha do Medo, sobrescrita em uma pintura de uma praia e um barquinho frente a uma palmeira, semelhante a uma dezena de imagens que eu havia visto naquela manhã na própria Ilha, em que os barquinhos estavam sempre ancorados na praia próximos as palmeiras.

Diante disso, não pude esconder a minha surpresa ao descobrir que o título do livro era uma coincidência e que não se referia a Ilha. Ainda assim, sem se dar conta da minha frustração, minha informante mostrava-me empolgada muitas gravuras da parte interna da obra como sendo retratos de sua própria "casa", como se referiam à Ilha.

Pensei de imediato que os ilhéus em sua maioria não soubessem ler, razão da confusão que transformou um livro de aventuras e ficção escrito para adolescentes no documento sagrado que narraria a história do local onde eles habitam. Mais tarde, descobri que quase todos na comunidade são alfabetizados, mas não têm o hábito da leitura e mesmo os que iniciaram a leitura da obra, tomaram para si e para sua Ilha a história criada para o entretenimento juvenil.

No meio da tarde chuvosa que se fez naquele primeiro dia de "exploração", seguimos para a construção da chamada trilha ecológica, sendo guiados por um morador, para que pudéssemos conhecer o outro lado da Ilha, vê-la do alto onde deve ser construído o mirante, e o mais importante, 
estabelecer os chamados pontos de descanso ${ }^{9}$ das trilhas ecológicas. Embora não fosse necessária a minha presença resolvi acompanhá-los nesse trajeto muito mais pela aventura do passeio do que pela busca de informações.

Mas como nos ensinou Malinowski (1978), o antropólogo deve mesmo estar sempre atento, pois as informações mais importantes nos são fornecidas nos momentos mais inesperados ou inoportunos. E durante o trajeto ouvimos do guia as histórias de perigo e assombração que povoavam a memória e a imaginação de todos no local. Passamos pelo poço misterioso onde o corpo de um estranho surgira e que perdeu por completo a sua utilidade por essa razão, tendo ficado "isolado".

Conhecemos o farol pichado, mistura de rural e urbano, com sua grade destruída demonstrando que fora forçado para a entrada de alguém. Conservação e destruição colocavam-se desde já como elementos da dicotomia que caracterizava e distinguia os nativos dos não-nativos.

Os profissionais da equipe deixaram a Ilha naquele fim do dia prometendo para o mais breve possível a visita de médicos, dentistas, e mais uma gama de profissionais da saúde que deveria cuidar de todos e que nunca se realizara.

Além disso, a partida dessa equipe depois de um dia de relações conflitantes instigava em mim mais uma dúvida: sobre quem eram os "invasores" de fato. Além da certeza de que os invasores não eram necessariamente, ou não apenas, os turistas, restou-me também a clareza de que a minha experiência etnográfica germinava e "se configurava como um campo articulado pelas tensões, ambigüidades e indeterminações próprias do sistema de relações do qual faz parte" (GONÇALVES, 2002, p.10).

9 Dentre outras técnicas adotadas pela turismologia, chamou-me a atenção a que é utilizada para a definição dos chamados pontos de descanso, que consistem em pontos de parada a serem arquitetados ao longo do trajeto da trilha ecológica, que devem conter mesinhas e banquinhos para o descanso dos turistas. Com esse fim, a equipe caminha até que um membro determinado previamente por eles sinta-se cansado, e cada parada feita por esse membro da equipe pressupõe um local importante para a construção de um ponto de descanso. 
Por fim, reflito sobre o convite que me fora feito pela SETUR para participar desta "exploração". Não acredito que esse convite revele certo conhecimento por parte da Secretaria em relação ao trabalho do antropólogo ou a reconhecida importância da presença de um antropólogo num primeiro contato com os autóctones, apesar de o conflito entre nativos e turistas está na base de grande parte dos estudos sobre o turismo hoje. Como constatei mais tarde, o convite deveria mesmo ser pró-forma, para dar sustentação ao projeto a ser encaminhado à Prefeitura de São Luís para transformar a Ilha do Medo num novo destino turístico. O intuito era de ter uma equipe o mais diversificada possível no que diz respeito à formação profissional de seus membros.

Na incômoda viagem de volta a São Luís, marcada por uma maré agitada e muitos sacolejos do catamarã, os integrantes da equipe de planejamento incrédulos demonstravam indignação diante da "resistência" dos ilhéus à implantação do turismo. Falavam da necessidade de um trabalho de sensibilização e conscientização para que a população soubesse o que exatamente ganharia com o turismo e da importância da interação com os "de fora", "os visitantes que eles chamam insistentemente de invasores". Deste modo, diziam que existia no local "duas ilhas dentro de uma mesma ilha", falando do isolamento a que se submetiam os ilhéus que se recusavam a aceitar os "visitantes".

Durante esta conversa uma turismóloga me falava do desejo de que fosse estabelecida uma parceria entre SETUR e Ilha do Medo e eu pensava que entender a lógica do Outro parecia o caminho viável para o estabelecimento desta parceria. Esse deveria ser o esforço a ser feito pelos planejadores do turismo.

Além do que, perguntava-me como seria possível transformar os "invasores" (para os ilhéus) em "visitantes" (para a SETUR)? Acredito que o visitante seja sempre desejado, convidado, esperado. Do contrário "invasão" é o termo que parece melhor definir o ponto de vista dos ilhéus. Se por um lado, como me disse um informante turismólogo, "o turismo trabalha para que o 
ISSN: $1982-6125$

visitante se sinta em casa", quando o turista se comporta como se estivesse em casa sua conduta parece um desrespeito à casa do nativo, pois o turista se comporta como se vigorassem no lugar as leis e regras de sua própria casa e não um modo de vida diferenciado e que deve ser respeitado. Seria este o paradoxo do turismo?

\section{A globalização como produtora do turismo e seus (não) lugares}

O turismo desponta como um dos fatores da contemporaneidade, por vezes considerada pós-modernidade, modernidade tardia, modernidade líquida (BAUMAN, 2001) ou entendida simplesmente como uma fase em que estão em evidência as conseqüências daquela mesma modernidade (GIDDENS, 1991).

Uma dessas conseqüências seria o que hoje chamamos de globalização, que embora não seja algo novo, nem se tenha um marco de sua origem, é um processo transformado em categoria analítica durante os anos 80 . Essas análises deram origem a preocupações que pareciam advir das conseqüências desse fenômeno, como o turismo.

Para Friedman (1994) a globalização está relacionada a dois ícones: a auto-identificação e o consumo. A primeira entendida como um ato consciente, uma afirmação em torno da relação entre o eu e o mundo. Já o consumo é um aspecto de uma estratégia mais generalizada ou um conjunto de estratégias para o estabelecimento e/ou manutenção da identidade. Este consumo não apenas de bens e produtos, pode ser pensado como consumo de lugares e pessoas, tal qual ocorre no fenômeno do turismo.

Segundo Friedman isso acarreta uma "transformação do ser-no-mundo". A identidade é dada pelo consumo, pensada aqui como a do turista que consome lugares. Pensar o consumo de lugares só se faz possível porque a contemporaneidade nos remete cada vez mais a distância cultural e as maneiras de atravessá-la (HANNERZ, 1997).

Hannerz (1997) sugere que as nossas teorias são hoje testadas em lugares onde as comunidades são diásporas e as fronteiras não imobilizam, 
mas são atravessadas. As teorias sociais hoje se dedicam a compreender a dinâmica dessas culturas em que o principal é estar em movimento e cujas fronteiras reservam os acontecimentos mais importantes. Este autor sugere que fluxos, fronteiras e híbridos seriam as palavras-chave dessa antropologia que se dedica aos fenômenos das "zonas fronteiriças", o lugar onde a cultura acontece ou é inventada (WAGNER, 2010): o entre-lugar (BHABHA, 2001).

A interessante teoria da cultura como entre-lugar de Bhabha (2001) trata das problemáticas fronteiras da modernidade, estas que foram feitas para serem atravessadas, gerando cada vez mais o que Althusser (apud BHABHA, 2001) definiu como "espaços sem lugares, tempos sem duração".

O fenômeno turístico faz desses lugares turísticos espaços sem lugares, e o tempo de permanência do turista é mesmo um tempo sem duração. A narrativa do "enquanto isso" de que trata Bhabha, nos permitiria pensar o encontro entre nativos e turistas como o tempo do "enquanto isso": uma coincidência espacial e temporal definida pelo complexo fenômeno turístico que faz dos lugares turísticos, lugares de circulação, lugares de anonimato.

Ora, há um lugar comum onde se encontram nativos e turistas? Este lugar não seria uma zona fronteiriça, um entre-lugar? Até que ponto poderíamos pensar as noções de lugares e não-lugares como experiências relacionais, no intuito de entender a dinâmica de nativos e turistas com o mesmo espaço, transformado por eles em um lugar ou em um não-lugar? Entendo que as noções de lugar e de não-lugar nos ajudam a compreender as relações sociais, mesmo que efêmeras, e a dinâmica que movimenta e transforma estes espaços ou lugares em experiências.

Cabe ressaltar que o lugar a que se refere Augé (1999) é um lugar antropológico e não espacial. Este lugar antropológico é o espaço onde ocorrem as relações sociais, onde se instaura toda experiência e sem o qual não se pode pensar a dinâmica das redes sociais, pois estas sempre são tecidas num espaço seja ele um espaço vivido, concebido, praticado ou um lugar. 
A Ilha do Medo é um lugar de encontro entre duas experiências distintas: dos nativos e dos turistas. Penso que falar da atribuição de sentidos de sujeitos diversos, distintos a um mesmo espaço construído como um lugar (ou nãolugar) é falar de pessoas e experiências mais do que de lugares. É pensar os fluxos através destes lugares, mas sem se deixar obstacularizar por eles. Especialmente porque as noções de sociedade, cultura, grupos sociais e pessoa, além das definições de relações sociais, nenhuma se constrói sem referência a espaços e lugares, ainda que tenhamos consciência de que "a cultura é um mapa que não se confunde com o território" (RODRIGUES, 1983).

Nesse sentido, o jogo de fluxos e fronteiras entre turistas e ilhéus se configura numa tensão constante que se realiza tendo a Ilha do Medo como palco. O medo aparece como uma fronteira, cujas histórias de mau-assombro e a exigência da arte de navegar para poder ultrapassar o boqueirão tenta manter os citadinos distantes. O medo é uma estratégia que serve como fronteira. Ora, mas como se dão esses fluxos pela fronteira do medo?

\section{Entre a terra de ninguém e o não pertencer a lugar nenhum}

O turismo constitui um fenômeno social uma vez que implica no deslocamento de inúmeras pessoas que passam a ser habitantes temporários de locais nos quais não residem, ocasionando impactos na sociedade receptora.

Com o contato entre culturas distintas, tem-se ampliado a vivência da alteridade, e como todo exercício de alteridade, a relação entre turista e anfitrião (voluntário ou involuntário) tem sido dialética e muitas vezes conflituosa, tanto quanto as opiniões e os estudos sobre o turismo, realizados por diferentes áreas de saber, como a antropologia, a turismologia, a economia, a geografia etc..

O mais importante é que parece despontar aí um confronto de identidades conferidas pelo turista, pela mídia e pelos nativos. E como toda identidade é uma "identidade narrada" (HALL, 2005), a identidade do local 
passa a ser a soma de todas essas representações dos sinais diacríticos em jogo.

O problema que se coloca desde já é o da relação entre nativos e nãonativos, ou os estabelecidos e os outsiders, fazendo uso das categorias de análise de Norbert Scotson (Elias e Scotson, 2000). Utilizo-me aqui das categorias analíticas de Elias com alguma ressalva, visto que no seu estudo clássico sobre Winston Parva a preocupação do autor é com as relações que se estabelecem entre os residentes antigos de um bairro da comunidade e os novos moradores do local. Na Ilha do Medo, as categorias de Elias nos permitem pensar as relações estabelecidas entre nativos que, embora não possuam a propriedade da terra, consideram-se estabelecidos, e os turistas que, por sua situação de passagem, são outsiders.

Os residentes que lá estão há mais de quarenta anos foram os primeiros a chegar ao local, pessoas advindas de municípios no interior do Maranhão e de bairros periféricos de São Luís, mulheres de cidades do interior que se casaram com alguns desses ludovicenses e acompanharam seus maridos na mudança para a Ilha do Medo.

Essa relação entre aqueles que habitam o local e foram os primeiros a chegar e os "de fora" colocam os primeiros em situação privilegiada, dando origem a um grupo coeso, cuja coesão é garantida pela identificação existente entre seus membros, que se diferem daqueles que freqüentam a Ilha em busca de diversão: os estranhos, os de fora, os outsiders.

A fronteira entre os habitantes do local e os forasteiros se estabelece por meio dos chamados sistemas classificatórios, responsáveis por aplicar princípios de diferença a uma população de tal forma que seja capaz de dividila em ao menos dois grupos opostos: nós/eles, eu/outro. Os sistemas de classificação operam na ordenação do social, produzindo diferença e garantindo, por meio das oposições binárias, a construção das identidades. Ademais, a sociedade separa funcional e territorialmente tudo e todos (BAUMAN, 1998). 
Os conflitos entre nativos e turistas estão na origem de toda a discussão sobre o turismo e tem seu cerne na divergência radical de objetivos, uma vez que o turista se entrega a uma atividade de prazer enquanto o nativo trabalha (ROBINSON, 1999).

É nesse sentido talvez que os moradores da Ilha do Medo se preocupam em defender o local onde moram embora saibam que não lhes pertence. Afirmam o tempo inteiro que não são donos, que pertence a União, que é monitorado pela Marinha. No entanto, emerge no discurso dos moradores, vez por outra, a expressão "terra de ninguém", que por isso passa a ser de quem habita, de quem cuida, de quem protege.

É interessante perceber que a narrativa dos nativos da Ilha do Medo em relação aos não-nativos é caracterizada pelo perigo trazido pelo desconhecido, "pessoas que não são daqui e que ninguém sabe de onde são", ou seja, pessoas de lugar nenhum, o que os transforma facilmente em perigosos e parece colocar os moradores da Ilha em situação de risco. Um risco eminente causado pelo contato com o Outro que, além de representar perigo no que se refere à violência física, pode transpor a fronteira da violência física para a cultural por representar uma ameaça aos moradores que lutam para proteger o local onde vivem, mantendo intactos os valores culturais.

Vale ressaltar que o contato repentino entre os estabelecidos e os outsiders esbarra nos ensinamentos da sociedade do "não fale com estranhos", que utiliza esta técnica de desvio e evasão como dispositivo de segurança para os indivíduos. A sociedade ensina-nos a lidar com a alteridade e seus lugares através de estratégias como a antropofágica (nos lugares fágicos), que tenta aniquilar a alteridade ingerindo, assimilando, devorando pessoas para fazê-las idênticas aos que as ingerem ${ }^{10}$; e a antropoêmica, cujo sentido é aniquilar o Outro, impedindo o contato, o diálogo, a interação, através da exclusão (transformando alguns lugares em lugares êmicos) (BAUMAN 1998; 2001).

\footnotetext{
${ }^{10}$ Lembramos que o turismo é um deslocamento coletivo, associado à expansão do Ocidente, que consome outras culturas e lugares.
} 
Há aqui uma confrontação entre dois mundos, duas identidades. A nativa, construída sobre as sólidas rochas da Ilha do Medo por um grupo coeso e solidário, que teme ver naufragar seu modo de vida a partir do contato e, mais especificamente, da apropriação que os estranhos farão de um território que eles entendem como sendo deles por ter servido de cais para a construção de um modo de vida sui generis. A outra identidade é a do turista, que está de passagem e por essa razão não se preocupa com o que deixará na Ilha do Medo, do lixo à representação que se construirá dela durante a sua estadia e que pode se prolongar por muito mais tempo.

Em "O mal-estar da pós-modernidade", Bauman (1998) apresenta o turista como uma metáfora do herói da contemporaneidade, sujeito que representa o processo de desencaixe espaço-tempo (GIDDENS, 1991) e a fluidez e a mobilidade da modernidade líquida (BAUMAN, 2001), ao mesmo tempo em que é vítima da "síndrome do turista". O turista seria então aquele que se recusa a se fixar em qualquer lugar que seja, vivendo o presente sempre recortado, separado do passado e do futuro, transformando o presente num "presente contínuo".

Assim, a construção da identidade do turista segue a regra do indivíduo da pós-modernidade, cuja identidade é circunstancial, efêmera, descartada e não está mais ancorada a quaisquer processos estruturais mais amplos (HALL, 2005). O deslocamento constante do turista permitiria a este a construção, desconstrução e reconstrução contínua de sua identidade transformada e adaptada a cada nova situação, garantindo o jogo da pós-modernidade onde as regras mudam a cada momento. Para Bauman: "o eixo da estratégia de vida pós-moderna não é fazer a identidade deter-se - mas evitar que se fixe. A figura do turista é a epítome dessa evitação" (BAUMAN, 1998, p.114).

O turista então realiza "a façanha de não pertencer ao lugar que pode estar visitando; é dele o milagre de estar dentro e fora do lugar ao mesmo tempo. O turista guarda sua distância, e veda a distância de se reduzir à proximidade" (BAUMAN, 1998, p.114). A mobilidade garante o jogo, cujo objetivo maior é estar em movimento e não chegar. 
Isto justificaria o tipo de relação estabelecida pelos turistas com seus anfitriões, definido por Bauman como "relações epidérmicas", portanto, superficiais. Para Bauman, este tipo de relação garantiria o "controle situacional" por parte do turista que pode escolher com que partes do mundo interfacear e quando desligar a conexão. Logo, o turista enxerga o mundo em sua estrutura e suas relações, a partir do seu olhar errante.

Este "controle situacional" a que Bauman se refere, encontra o seu suporte no fato de que o turista opta por estar em movimento, mas pode voltar ao lar e à rotina doméstica quando desejar, e é essa certeza do retorno possível a qualquer momento ao seu mundo estável que dá ao turista o caráter de não pertencer a "lugar nenhum" mesmo quando permanece em algum lugar.

Por essa razão, para Bauman, o turista não transforma e não deseja transformar estes lugares em sua casa nem as relações superficiais, "epidérmicas", em sólidas ou duradouras. Se, por um lado, as relações epidérmicas e superficiais garantem ao turista este controle situacional, por outro, elas geram aquilo que Bauman define como a "síndrome do turista" caracterizada pela perda dos laços com o lugar (geográfico e social) que o tornaria vítima de um dos mal-estares da pós-modernidade.

A presença do turista reforça e legitima a tradição (reinventada ou encenada) da comunidade e, mais do que isso, apresentando-se como forasteiro e, portanto, uma ameaça à integridade cultural por atentar contra a consciência comum cristalizada nas tradições e costumes, o turista contribui com a comunidade no fortalecimento dos laços sociais.

Se, por um lado, os nativos alegam que os turistas, "invasores", pertencem a lugar nenhum, o olhar do turista e a sua não-identificação com o lugar termina por transformá-lo em um não-lugar, nos termos de Marc Augé (2004), ou num lugar não-dito, como assim o define Michel de Certeau (1994).

Em sua teoria dos não-lugares, Marc Augé, para quem a supermodernidade é produtora de não-lugares, critica a noção sócioantropológica de lugar construída pela etnologia a partir de uma compreensão 
de cultura localizada no tempo e no espaço, e transformada por Mauss (2003) em seus fragmentos num fato social total.

O lugar antropológico, segundo Augé, teria um princípio de sentido para aqueles que o habitam e um princípio de inteligibilidade para quem o observa. Seriam então os lugares de memória de Pierre Nora (1993), "onde aprendemos essencialmente nossa diferença, a imagem do que não somos mais". Por isso, para os turistas, esses lugares de memórias não existem, os não-lugares que freqüentam não detêm passado nem futuro, enquanto o lugar é sempre identitário, relacional e histórico.

Os não-lugares, em contrapartida aos lugares sociológicos, são lugares de deslocamento, onde os sujeitos que o ocupam o fazem transitoriamente sem que se construa uma identificação com aquele lugar. É assim que, no que se refere ao turista, sua parada ou permanência nesses lugares de passagem o transformam num não-lugar. Conforme Augé, a viagem turística é constitutiva de não-lugares; quem viaja não faz senão passar de um lugar a outro (AUGÉ, 1999, p.145). Podemos considerar que o turista se desloca em busca de outra realidade, diferente daquela que vivencia em seu cotidiano. Busca, pois, o extraordinário que rompe com a prática cotidiana engendrando um outro modo de olhar as coisas a sua volta.

Ao se referir aos não-lugares, Bauman (2001) afirma que esses espaços interditórios foram desenhados para serem circundados, atravessados, razão pela qual está repleto de passantes, transeuntes. Nos não-lugares, todos devem se sentir como se estivessem em casa, mas ninguém deve comportarse como tal, especialmente porque estes espaços são engendrados para serem atravessados e deixados para trás o mais rapidamente possível.

Essa idéia nos remete sobre um ângulo aproximado a Michel de Certeau e a sua teoria do espaço praticado. Ao distinguir espaços de lugares Certeau (1994) afirma que o espaço é o efeito produzido pelas operações que o orientam, circunstanciam, temporalizam e o levam a funcionar em unidade polivalente de progresso conflituais ou de proximidade contratuais. Diverso do lugar, o espaço não tem a univocidade nem a estabilidade de um próprio: 
ISSN: $1982-6125$

deste ponto de vista, existem tantos espaços quantas experiências espaciais distintas. A perspectiva é determinada por uma fenomenologia do existir no mundo. Assim, o espaço é um lugar praticado. O espaço geométrico é diferenciado do espaço antropológico para o qual o espaço é existencial e a existência espacial (CERTEAU, 1994).

Ainda para Certeau, a definição do espaço praticado enquanto lugar passa pela metáfora da linguagem: "o espaço seria para o lugar o que se torna a palavra quando é falada", pois, apenas quando é falada, é que a palavra ganha e impõe um sentido, torna-se inscrita num contexto que lhe confere sentido. Certos lugares só existem pelas palavras que os evocam, nãolugares são lugares não-ditos que garantem o anonimato daqueles que por eles transitam. Assim, um não-lugar de Marc Auge seria o lugar não-dito ou o lugar não praticado de Certeau.

Ao discorrer sobre o viajante, Certeau caracteriza o seu espaço como o arquétipo do não-lugar, onde nem a identidade, nem a relação, nem a história fazem realmente sentido. Esse movimento do viajante não tem outro fim senão ele mesmo.

Pensando os chamados destinos turísticos como não-lugares, acredito que, se a supermodernidade, como define Augé a atualidade, é rica no surgimento e proliferação de não-lugares, o turismo se torna um dos grandes empreendimentos da contemporaneidade por expandir essa apropriação descompromissada dos indivíduos pelos não-lugares, garantindo deslocamentos de grandes massas de sujeitos tendo este fim por ele mesmo.

Em meio a essa apropriação dos lugares pelos turistas e a constante transformação destes lugares em não-lugares é que emerge o conflito entre turistas e autóctones, pois se estabelece uma preocupação entre integridade e contaminação como demonstrada cada vez que os nativos tratavam do desejo de manutenção da identidade do grupo, reforçando a construção social do conservadorismo cultural num tempo em que se fala cada vez mais em culturas híbridas, etnicidade reconstruída, o global e o local, fluxos e fronteiras (HANNERZ, 1997). Entretanto, é preciso lembrar que o sentimento de uma 
ISSN: $1982-6125$

identidade comum é uma fabricação da experiência compartilhada no interior das fronteiras, sejam elas territoriais, ou culturais.

Assim, o discurso dos nativos se fortalece a partir de concepções dicotômicas que se assemelham às relações entre eles mesmos e os "intrusos": tradição versus modernidade, localização versus globalização, dentro versus fora, hospedeiro versus visitante, integridade versus contaminação.

Todavia, a antropologia contemporânea tem nos alertado sobre os riscos de empobrecimento das análises que se mantêm circunscritas às dicotomias. Há muito mais complexidade entre estes grupos e suas representações internas do que esses esquemas dicotômicos/simplificados poderiam revelarnos. Não há harmonia nem coesão no que se refere às representações, mas, como nos diz Weber (2004), se "a realidade é um caos, a tarefa do pesquisador é ordená-la". Um estudo minucioso das trajetórias dos nativos da Ilha do Medo em seus depoimentos revelar-nos-ia, talvez, outros interesses e desejos que legitimariam o processo de implantação do turismo na Ilha.

Neste artigo detive-me a uma análise das representações dos nativos sobre os turistas e, especialmente, da relação que se estabelece entre os autóctones e os planejadores de turismo. Sem perder de vista, claro, que as redes que se constroem em torno destas relações e suas dinâmicas, jamais se deixarão apreender pela simplificação das dicotomias ou pela armadilha do discurso do grupo e da representação que se quer coesa, harmônica e hegemônica.

A análise sobre o comportamento do turista na contemporaneidade se fundamenta muito mais nas teorias atuais sobre o turismo, numa tentativa incessante de lançar luz sobre a reação dos autóctones numa garantia de uma melhor compreensão da situação que os ilhéus vivenciaram.

\section{Considerações finais}


Este artigo se compõe de todos os conflitos e tensões estabelecidos no campo e aqui narrados, que resultam da minha experiência como antropóloga junto a uma equipe de profissionais diversos, responsável pelo projeto de implantação do turismo na Ilha do Medo; da representação que se estabelece pelos nativos dos turistas; e da relação que se instaura entre os nativos e a equipe de profissionais que são relacionados pelos ilhéus à Prefeitura de São Luís, que sempre agiu com descaso em relação à Ilha do Medo.

Dentre estes, o conflito maior que parece ser o invólucro de todas as outras tensões é o que se cria entre residentes e turistas pelo fato dos primeiros sentirem-se inseguros ao verem o lugar onde habitam repleto de estranhos cuja origem e destino são desconhecidos.

Ademais, como nos diz Grünewald "o turista é percebido como um 'neonômade' que, apesar de reconhecer fronteiras, sustenta uma consciência desterritorializada" (GRÜNEWALD, 2001, p.31). A situação de nomadismo dos turistas cria entre os anfitriões (sedentários) o sentimento de risco uma vez que este sentimento está associado ao desconhecimento do Outro. Ser nômade e estar de passagem é estar livre de compromissos com regras locais ou pessoas.

Afora isso, Bauman (2001) nos lembra que a guerra na modernidade líquida não é pela posse do território ou pelo desejo de fixação, mas pelo direito ao fluxo, numa espécie de "vingança do nomadismo" que, com seu poder extraterritorial, dominaria a maioria assentada.

Um aspecto a ser considerado é que a indústria turística não deve privilegiar unicamente os turistas, esquecendo que os produtos culturais têm origem em atores sociais com representações próprias sobre os espaços que partilham com aqueles que os visitam. Desta forma, a qualidade de vida das populações e o enriquecimento mútuo entre população e visitantes deveria ser uma preocupação dos modelos turísticos. Nos contatos culturais está sempre presente uma possibilidade de conflito que não deve ser alimentado pela indústria turística. 
Por fim, é importante ressaltar a necessidade da construção, no exercício da escrita etnográfica, de textos mais polifônicos, uma vez que os estudos sobre o turismo, mesmo na antropologia, estão ainda muito centrados no próprio turista. Numa espécie de antropologia de nós a voz dos autóctones continua inaudível.

É preciso lembrar que os autóctones são agentes importantes neste processo e que este turismo passional tem esperado sempre que eles se adaptem aos turistas e não o contrário, o que caracteriza uma atitude etnocêntrica.

Uma antropologia dos hóspedes ou anfitriões, numa análise do turismo como fenômeno social, é possível e deve ajudar a compreender a lógica do Outro, do nativo, como nos dizia Malinowski (1978), tarefa maior do antropólogo.

Desde 2006, devido à resistência colocada pelos moradores da Ilha do Medo, a SETUR suspendeu o projeto de implantação do turismo comunitário. Com as diversas mudanças no Governo do Estado e na prefeitura de São Luís e a característica de descontinuidade administrativa de que sofre o município e o Estado, o projeto de implantação do turismo na Ilha do Medo terminou sendo abandonado. ${ }^{11}$

Nesta incursão, detive-me a uma análise das representações dos nativos sobre os turistas e, especialmente, na construção de um mecanismo pelos nativos para manter os turistas ou "invasores" distantes: o medo.

Assim, sem perder de vista as relações que se estabelecem entre os autóctones, os turistas, os planejadores de turismo e eu, busquei apreender os mecanismos a partir dos quais os nativos tentam manter os turistas fora da Ilha do Medo, mecanismos estes fundamentados nas representações que os nativos fazem destes turistas.

\footnotetext{
${ }^{11}$ Ressalto que a época deste projeto o prefeito da cidade era Tadeu Palácio e o governador era José Reinaldo Tavares que foi sucedido em 2007 por Jackson Lago que foi cassado em 2009 passando o governo do Estado para Roseana Sarney.
} 
Numa próxima "exploração", pretendo coletar as histórias de mauassombro locais, com fins de entender que elementos as embasam, sua estrutura e sua eficácia na utilização do medo como dispositivo para manter os turistas distantes.

\section{Referências}

ARAÚJO, Silvana Micelli de. Artifício e autenticidade: o turismo como experiência antropológica. In: BANDUCCI JR., Álvaro; BARRETTO, Margarita (Orgs.). Turismo e identidade local: uma visão antropológica. Campinas: Papirus, 2005, p.49-63. (Coleção Turismo)

AUGÉ, Marc. Não-lugares: introdução a uma antropologia da supermodernidade. 4.ed. Campinas: Papirus, 2004. (Coleção Travessia do Século)

Vozes, 1999.

O sentido dos outros: atualidade da antropologia. Petrópolis:

BANDUCCI JR., ÁLVARO. Turismo e Antropologia no Brasil: estudo preliminar. In: BANDUCCI JR., Álvaro \& BARRETTO, Margarita (Orgs.). Turismo e identidade local: uma visão antropológica. Campinas: Papirus, 2001. (Coleção Turismo)

BAUMAN, Zygmunt. O mal-estar da pós-modernidade. Rio de Janeiro: Jorge Zahar Editor, 1998.

. Modernidade líquida. Rio de Janeiro: Jorge Zahar Editor, 2001.

BHABHA, H. DisseMinação. o tempo, a narrativa e as margens da nação moderna. In: O local da cultura. Belo Horizonte: UFMG, 2001.

CERTEAU, Michel de. A Invenção do cotidiano: 1. Artes de fazer. Petrópolis: Vozes. 1994

DAMATTA, Roberto. O ofício do etnólogo: ou como ter um 'Anthropological Blues'. In: NUNES, E. (Org.) A aventura sociológica. Rio de Janeiro: Jorge Zahar Editor, 1978. p.23-35.

DIEGUES, Antonio Carlos. O mito moderno da natureza intocada. São Paulo: Hucitec, 1996.

ELIAS, Norbert; SCOTSON, John L. Os estabelecidos e os outsiders: sociologia das relações de poder a partir de uma pequena comunidade. Rio de Janeiro: Jorge Zahar Editor, 2000.

GIDDENS, Anthony. As conseqüências da modernidade. São Paulo: UNESP, 1991.

GONÇALVES, José Reginaldo Santos. Apresentação. In: CLIFFORD, James. $A$ experiência etnográfica: Antropologia e Literatura no século XX. Rio de Janeiro: UFRJ, 2002. P.7-16.

GRÜNEWALD, Rodrigo de A. Os índios do descobrimento: tradição e turismo. Rio de Janeiro: Contra Capa, 2001. 
FRIEDMAN, Jonathan. Ser no mundo: globalização e localização. In: FEARTHERSTONE, M. (Org).. Cultura global: nacionalismo, globalização e modernidade. Petrópolis: Vozes, 1994.

HALL, Stuart. A identidade cultural na pós-modernidade. Rio de Janeiro: DP\&A, 2005.

HANNERZ, Ulf. Fluxos, fronteiras, híbridos: palavras chave da antropologia transnacional. In: Mana, 3/1, abril 1997.

MALINOWSKI, Bronislaw. Argonautas do Pacífico Ocidental: um relato do empreendimento e da aventura dos nativos nos arquipélagos da Nova Guiné Melanésia. 2.ed. São Paulo: Abril Cultural, 1978. (Coleção Os Pensadores).

PORTELA, J. \& CASTRO CALDAS, J. (Coords.). Portugal chão. Oeiras: Celta. P.231-247.

MAUSS, Marcel. Sociologia e Antropologia. São Paulo: Cosac \& Naify, 2003.

NORA, Pierre. Entre Memória e História: a problemática dos lugares. Revista do Programa de Estudos Pós-Graduados em História e do Departamento de História da PUC. São Paulo: PUC, 1981.

ROBINSON, Mike. Por um turismo consensual. O Correio da UNESCO, Unesco. 1999, pp.22-23.

RODRIGUES, José Carlos. O tabu do corpo. Rio de Janeiro: Achiamé, 1983.

SOUSA, Emilene Leite de. "Invasão" à Ilha do Medo: o processo de implantação do turismo e a reação dos autóctones. In: Cadernos de Campo: Revista de Pós-Graduação em Antropologia Social da USP, vol. 16, n. 16, 2007.

WEBER, Max. Weber: Sociologia. 7.ed. São Paulo: Ática, 2004. (Coleção Grandes Cientistas Sociais)

Artigo recebido em agosto de 2011.

Aprovado para publicação em novembro de 2011. 